\title{
BAUER ERVIN: A HALÁLOS ÍTÉLETTŐL AZ EMLÉKMŰ LELEPLEZÉSÉIG
}

\section{ERWIN BAUER: FROM THE DEATH SENTENCE TO THE UNVEILING OF THE MEMORIAL}

\author{
Müller Miklós ${ }^{1}$, Elek Gábor ${ }^{2}$ \\ 1 az MTA külső tagja, professor emeritus, orvosdoktor, The Rockefeller University, New York, NY, USA \\ mmuller@rockefeller.edu \\ 2 a biológiai tudomány kandidátusa, orvosdoktor, nyugalmazott patológus \\ elekgabor212@gmail.com
}

\begin{abstract}
ÖSSZEFOGLALÁS
Bauer Ervin (Эрвин Симонович Бауэр) (1890-1938) magyar-szovjet biológus kutató, az elméleti biológia egyik megalapítója volt. Pályafutását Budapesten kezdte, 1919-ben emigrációba kényszerült, rövid ideig Bécsben, Prágában, Göttingenben, Berlinben dolgozott, majd 1925-ben bevándorolt a Szovjetunióba, ahol Moszkvában és Leningrádban vezető kutatói állásokban múködött. Fő műve, az Elméleti biológia 1935-ben jelent meg oroszul. Feleségével, Szilárd Stefániával együtt 1937-ben letartóztatták, és hamis vádak alapján 1938 elején kivégezték. Műveit megsemmisítették. Főművét csak 1956. évi rehabilitációja után adták ki újra, először magyar fordításban, majd több kiadásban oroszul. Ma már elismerik úttörő szerepét a modern biológia történetében. A nagy terror áldozatainak levasovói (Szentpétervár) emléktemetőjében 2019ben avatták föl az Össz-szövetségi Kísérleti Orvostudományi Intézet mártírjainak emlékmúvét, amelyen a harminckét név között az övét és feleségéét is megtaláljuk.
\end{abstract}

\section{ABSTRACT}

Erwin Bauer (Эрвин Симонович Бауэр) (1890-1938) Hungarian-Soviet biologist was one of the founders of theoretical biology. He started his research career in Budapest. After emigrating from Hungary in 1919 he worked in Vienna, Prague, Göttingen, Berlin. Finally he moved to the USSR in 1925 where he occupied leading research positions in Moscow and Leningrad. His chef-d'oevre, Theoretical Biology, was published in Russian in 1935. He was arrested together with his wife, Stefánia Szilárd in 1937 and based on trumped up charges both were executed in early 1938. His works were destroyed, and his chef-d'oevre was republished only after his rehabilitation in 1956, first in Hungarian translation and subsequently in several editions in Russian. Today he is recognized for his pioneering role in the history of modern biology. In the cemetery of the victims of the great terror in Levashovo (Saint-Petersburg, Russia) a memorial was erected in 2019 for the martyrs of the Institute of Experimental Medicine, showing his and his wife's name among the 32 victims. 
Kulcsszavak: elméleti biológia, Bauer-elv, Kísérleti Orvostudományi Intézet, sztálini nagy terror, levasovói emléktemető

Keywords: theoretical biology, Bauer's principle, Institute of Experimental Medicine, Stalin's great terror, Levashovo Memorial Cemetery

A 18. század a fizika diadalmenete volt. A konkrét megfigyelések és a kísérleti eredmények elemzése átfogó elméleti rendszerekhez vezetett: kiteljesedett az elméleti fizika. Az elméleti tudomány feladata Albert Einsteint idézve: „egyrészt minden érzéki tapasztalat lehető legátfogóbb, totális és összefüggő megértése, másrészt, ugyanezen cél elérése minimális primer fogalmak és relációk útján" (Einstein, 1950, 63.). A biológusok ezekbe a törekvésekbe később kapcsolódtak be: csak a 20. század elején merült fel hasonló szinten az elméleti biológia létrehozásának lehetősége. Megemlíthetjük Jakob von Uexküll, Ludwig von Bertalanffy, Julius Schaxel, Ilya Prigogine és több más tudós nevét, akik megpróbálták e feladat megoldását.

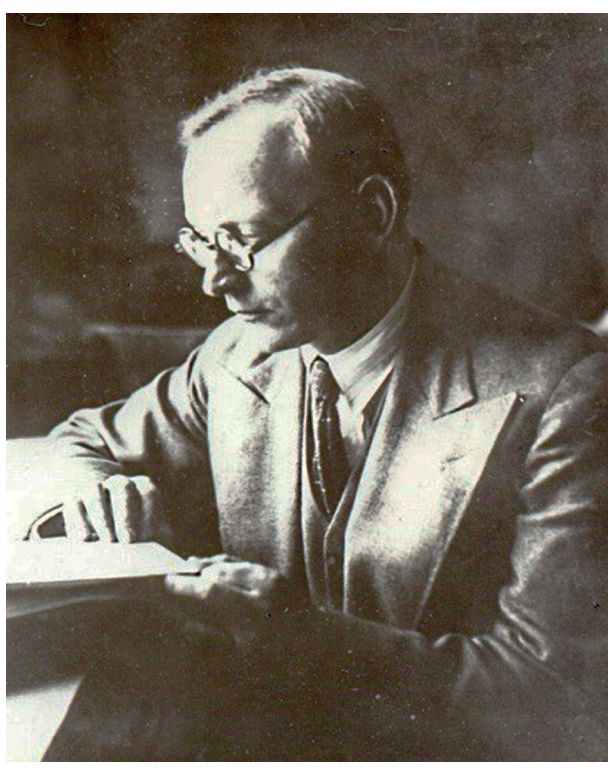

1. kép. Bauer Ervin (1890-1938) (Szvetlana Bauer engedélyével)

Bauer Ervin magyar-szovjet biológus kutató (1. kép) egész munkásságát ennek a célnak szentelte. Annyira Einstein megfogalmazása szerint alkotott, hogy a nagy fizikussal való párhuzam - ha érintőlegesen is - tudományos körökben már Bauer életében feltűnt (Elek-Müller, 2019). A fiziológus Alekszej Uhtomszkij, Bauer leningrádi kollégája különlenyomatát a következőképpen dedikálta Bauernek - A biológia Einsteinjének. Erről Bauer idősebb fia ír (Бауэр, М., 2003, 286.). A legfontosabb - és egyetlen - reláció, melyre Bauer elméleti biológiáját 1920tól kezdődően alapozta, a következő: Az „élő és csakis az élő rendszerek soha sincsenek egyensúlyban és szabadenergia tartalmuk terhére állandóan munkát végeznek annak az egyensúlynak a beállta ellenében, amelynek az adott külső feltételek mellett a fizikai és kémiai törvények értelmében létre kellene jönnie" (Bauer, 1967, 51.). Ezt a tételt leírója után Bauer-elvnek nevezzük. Röviden így fejezhetjük ki: az élö rendszerek állandó in-equilibriumának elve (Tokin, 1965b, 46.). Bauer ebből az elvből következetes elméletet vezetett le, amellyel magyaráz- 
ta az összes életjelenséget. Ezt a feladatot mesterien oldotta meg - elmélete annak idején korszerü volt.

Bauer Lőcsén (ma Levoča, Szlovákia) született, 1890. október 14-én. Szülei tanáremberek voltak. A Szovjetunióban korábban kitöltött személyi lapokon magyar nemzetiségűnek és csehszlovák állampolgárnak vallotta magát. Letartóztatásakor feleségével együtt már szovjet állampolgárok voltak. Bauer sohasem tagadta meg magyarságát, és ezt az orosz kutatók is elismerik, legtöbbször mint magyar-szovjet tudóst említik. Első elméleti munkáját 1920-ban Budapesten kezdte írni (Müller, 2005). 1930-ban kiadott második monográfiájának címoldalán még nem használja az oroszra jellemző apai nevet (Симонович). Noha hazáját soha nem láthatta viszont - egyik utolsó közleménye egy Magyarországon kiadott folyóiratban (Acta Cancrologica) jelent meg.

Bauer orvosi tanulmányait Budapesten és Göttingenben folytatta. 1914-ben Budapesten diplomázott. Első felesége (az írónő Kaffka Margit) halála után a Tanácsköztársaságban való részvétele miatt második feleségével, a matematikus Szilárd Stefániával emigrált. Az emigráció évei Bécsben, Göttingenben, Prágában és Berlinben különböző orvosi intézményekben teltek egészen 1925-ig, amikor a szovjet egészségügyi hatóságok meghívták a moszkvai Obuh Munkaegészségügyi Intézet kísérleti patológiai laboratóriumának megszervezésére. A Szovjetunióban mint kutatót megbecsülték. Vezető állásban volt a Kommunista Akadémia Tyimirjazev Biológiai Intézetében, majd a Szovjetunió első számú egészségügyi létesítményében, az Össz-szövetségi Kísérleti Orvostudományi Intézetben. Professzori állása volt a moszkvai II. Orvosegyetemen. Felkérték a Nagy Szovjet Enciklopédia első kiadásának (1932) élet címszava megírására és az első orosz nyelvű egyetemi biológiai tankönyv szerkesztésére (Müller-Elek, 2016).

Bauer tételét három monográfiában fejtette ki. Az első: A tisztán tudományos biológia alapjai még német nyelvü, rövidebb módszertani összefoglaló (Bauer, 1920). A második, A biológia fizikai alapjai már orosz nyelvü (Бауэp, 1930), úgyszintén az a harmadik, Bauer fö müve, az Elméleti biológia (Бауэр, 1935). Az első és a harmadik Müller Miklós fordításában magyarul is megjelent egy közös kötetben (Bauer, 1967), a másodiknak nincs magyar fordítása.

„Bauer alkotó munkássága 1937 augusztusáig tartott, amikor is őt és feleségét hamis vádak alapján letartóztatták. 1942-ben bekövetkezett halála jelentős kutatótól fosztott meg bennünket. Felesége pár évvel előbb halt meg." (Tokin, 1965b, 26.) Korábban ezt az időpontot fogadta el minden írásmü. Ideje, hogy rekonstruáljuk Bauer és felesége tragikus sorsának eseményeit az újabban feltárt dokumentumok alapján. A Bauer házaspár „bűn”-ügyének iratai a Szövetségi Biztonsági Szolgálat Szentpétervári és Leningrád Területi Igazgatóságának (Управление Федеральной службы безопасноснти [УФСБ] по Санкт-Петербургу и Ленинградской области) archívumában találhatók (az ügy utolsó, végleges száma № П-13869-37). 
A Bauer házaspár a sztálini nagy terror (1937-1938) „,nemzetiségi intézkedéseinek" áldozata volt. Az NKVD, a Belügyi Népbiztosság (Народный комиссариат внутренних дел) nagyszabású múveletei a Szovjetunió nemzetiségi kisebbségei ellen (lengyelek, németek, litvánok, lettek, észtek és mások) irányultak. Céljuk a kapitalista országok kémei és diverzáns-forradalmárai elleni harc volt. Emiatt 1937 augusztusa és 1938 novembere között összesen 335513 személyt ítéltek el, közülük 247 157-et golyó általi halálra.

A belügyi népbiztos 1937 . július 25 -i, 439. sz. távirati parancsa kötelezte az NKVD helyi szerveit, hogy öt napon belül tartóztassák le az összes német állampolgárt, aki hadiüzemben, vasútnál vagy hadifontosságú részleggel rendelkező üzemben dolgozik vagy dolgozott. E parancs kibocsátása után öt nappal - augusztus elsején - a 4326 sz. határozat intézkedik Bauer Ervin Szimonovics polgártárs letartóztatásáról és kivizsgálásáról. Bauer idősebb fia, Mikhail így emlékezik: ,37 nyarán a Bauer és Muzsejev család közös nyaralót bérelt Razliv faluban... A nyár eleje olyan volt, mint mindig, úsztunk, futballoztunk amíg csak be nem sötétedett... Minden nagyon jó volt augusztus másodikáig-negyedikéig..."

„Augusztus úgy kezdődött, hogy mamát elvesztettem szemem elől, de még nem tudtam, hogy nem látom többé. Két-három napig nem is aggódtam. Augusztus 4-én papa három férfi kíséretében érkezett meg az intézet gépkocsiján. Az egyiket már láttam korábban, ő volt az intézet pártbizottságának titkára... Mindenkit kiküldtek az udvarra, és az újonnan érkezettek papával bementek a szobába. Nemsokára mindnyájan kijöttek. Papa hozzám és mindenkihez fordulva ezt mondta: »Ez valami félreértés, nemsokára visszajövök.« Ezek voltak az utolsó szavai. Az autó elment, papát is elvitte. Karcsi kisöcsémmel és Katjával, háztartási alkalmazottunkkal egyedül maradtunk. Ilyen szavakat hallottam: »házkutatás«, »letartóztatás«" (Бауэр, М., 2003, 53-54).

„A vád összefoglalása a ... megvádolt Bauer, E. Sz. és Bauer, Sz. Sz. 419411937 számú bünügyében (az ügyirat 26. oldala).”

„A Leningrádi kerület Államvédelmi Hatóság 4. Osztálya 1937-ben arról kapott értesítést, hogy Bauer Ervin és Bauer Stefánia, a Kísérleti Orvostudományi Intézet két munkatársa, akik 1924-ben Németországból érkeztek, szovjetellenes tevékenységet folytat. Ezért 1937. augusztus 3-án mindketten letartóztatásba kerültek.” Kihallgatásuk alapján

\section{„MEGVÁDOLJUK}

a lőcsei születésű Bauer Ervint és Bauer Stefániát azzal, hogy ellenforradalmi német nacionalista propagandát folytatott. Dicsérte a németországi fasizmust, szidalmazta a Szovjet Kommunista Pártot, egyetértett a trockisták-zinovjevisták terrorista tevékenységével, mely a kommunista párt és a szovjet állam vezetői ellen irányul. Ezzel elkövették az Orosz Szövetségi Köztársaság Büntető Törvénykönyvének 58-8 és 58-10 paragrafusában meghatározott büncselekményt. Mindketten elismerték bünösségüket. Az ügyiratokat megküldtük az NKVD 485. 
számú parancsa alapján a Belügyi Népbiztosságnak, Jezsov elvtársnak.” Ezt az összefoglalót 1938 márciusában fogalmazták meg - három hónappal a kivégzés után! Figyelemre méltó, hogy ekkor már nem a németek ellen kiadott 439. sz. parancsra hivatkoztak, hanem a lengyelek elleni $485 \mathrm{sz}$. parancsra.

Bauerrel 1937. augusztus 17-én közölték ezt a döntést. Pár hónap múlva halálra ítélték. Valójában nem 1942-ben halt meg, mert Polikarpov KGB-föhadnagy az 1938. január 6-án hozott halálos ítéletet már január 11-én végrehajtotta (Müller, 2005).

A nép ellenségeinek minden müvét bezúzták. Bauer könyveinek is ez lett a sorsa. Csak néhány példányt őriztek meg egyes könyvtárak elzárt, különleges részlegeiben. Az Elméleti biológiát egyszerü volt eltüntetni. Mint elvont tudományos művet, létezését egyszerüen le lehetett tagadni. Mint egy misztikus müről sokan hallottak róla, de kevesen tartották valaha is kezükben. Később többen is megírták, hogyan jutottak hozzá, amikor még tiltott gyümölcs volt.

$\mathrm{Az}$ Általános biológiára mint tankönyvre azonban nagy szükség volt. Ezért Bauer szerzőségének eltüntetése után a kissé átdolgozott mü továbbra is betölthette szerepét. További három kiadásban jelent meg, 1939-ben, 1940-ben és 1944-ben, mindig nagy példányszámban. A szerzők száma egyre csökkent, ahogy száműzetésbe kerültek, vagy meghaltak. Mikor a biológiában Trofim Liszenko szemlélete győzött 1948-ban, az Általános biológia is eltünt a sülylyesztőben (Müller-Elek, 2016).

Bauer Ervint és feleségét 1956. április 28-án rehabilitálták - büncselekmény hiányában. A rehabilitációs tárgyaláson sokan bizonyították ártatlanságukat (Бауэр, М.-Голиков, 2002). De a tragédiáról történő méltó megemlékezésig még sokáig kellett várni.

Erről tanúskodik a Bauer fiához írt levél dátuma. „1992 január 20. No.10/447376-I. Szentpétervár Város. Tisztelt Mikhail Ervinovics! Közöljük Önnel, hogy a Bauer Ervin és Stefánia ellen hozott ítéletet Leningrádban 1938 január 11-én hajtották végre... Az 1938. évi repressziók leningrádi áldozatait Levasovóban, Leningrád Viborg kerületében temették el. A temetés helyén egy emléktemető épül. Kérjük, hogy fogadja őszinte együttérzésünket azzal a tragédiával kapcsolatban, mely Önt és családját a represszió éveiben érte. A. E. Psenicsil, alosztályvezetö" (Müller, 2005, 128.).

A levasovói emléktemetőben nemrégen márvány emlékmüvet állítottak $A K i$ sérleti Orvostudományi Intézet sztálini terror idején kivégzett vagy munkatáborokban elpusztult munkatársainak, amelyet 2018. július 9-én avattak fel (2. kép). A harminckét áldozat neve között Bauer és felesége neve is szerepel.

Emléktáblát helyeztek el a szentpétervári Kísérleti Orvostudományi Intézetben is, melynek avatása 2018. október 30-án történt (Zakharova et al., 2018). Bauert és feleségét - mint embert - tehát rehabilitálták. De hogyan kelt újra életre munkásságuk? 


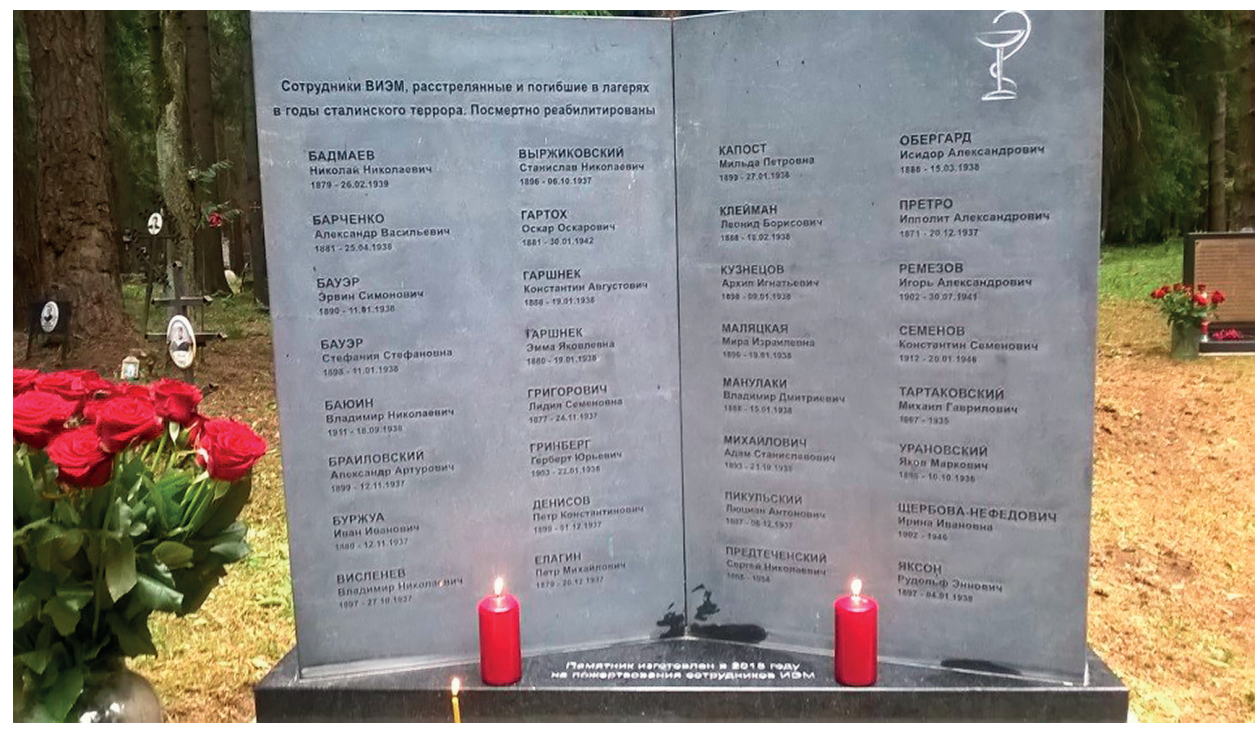

2. kép. A levasovói emlékmű (Elena Zakharova engedélyével)

Az első lépést Borisz Petrovics Tokin (1900-1980) tette meg, aki 1931-től 1937-ig a Kommunista Akadémia Tyimirjazev Biológiai Intézetének igazgatója volt, és mint ilyen Bauer főnöke és egyben barátja. Később a Leningrádi Egyetem professzorává nevezték ki. Ekkor kezdte emlékeit és véleményét publikálni Bauer Ervinről. Magyarországra is eljött, hogy kibővítse adatait Bauerről. Budapesti előadása magyarul is megjelent: „Azt remélem, hogy szovjet tudóstársaim, magyar barátaim és mindenki, aki csak ismerte Bauer Ervint, előadásomat egy nagy tudós életmüve előtt lerótt tiszteletadásnak tekinti” (Tokin, 1965a). Könyvet írt Bauerről, mely két kiadást is megért. Ez a könyv Müller Miklós fordításában megjelent magyarul (Tokin, 1965b).

A rehabilitációt követően Bauer 1935. évi föművének több új kiadása jelent meg (3. kép). Tokin magyarországi kapcsolatainak köszönhetően az 1967-es magyar fordítás volt az első újrakiadás (Bauer, 1967, 3. kép A). A Tokin-életrajz és az Elméleti biológia megjelenését élénk sajtóvisszhang kísérte Magyarországon. Ennek ismertetése itt nem áll módunkban.

Ezt követte 1982-ben a mű első orosz nyelvű facsimile kiadása, fejezetenként angol összefoglaló kivonattal (3. kép B). Ez is a budapesti Akadémiai Kiadóban jelent meg hazai és szovjet tudósok együttes munkájának eredményeképpen. A kiadvány sorsa nem volt szerencsés. A szerkesztőbizottság 1982-ben még fiatal orosz tagja, A. A. Zamjatnin 2019-ben a következőt írja Müller Miklóshoz intézett levelében: „Tíz évet töltöttünk a kiadás előkészítésével, de végül is a könyv megjelent. És ezután jöttek a nem várt nehézségek... Az orosz könyvforgalmazó 
vállalathoz (Международная Книга) fordultunk azzal a kéréssel, hogy vállalja magára a könyv terjesztését a Szovjetunióban. Nem kaptunk hivatalos visszautasítást, de a reagálásukból világos lett a válasz: »hogyan lehetséges az, hogy külföldön anélkül jelentetnek meg egy könyvet, hogy az terveinkben szerepelt volna, és akkor azt mi még terjesszük is?« - Sokáig elhúzódott mindez, de próbálkozásaink eredménytelenek maradtak. Később Tigyi József (a szerkesztőbizottság magyar tagja) említette nekem, hogy a (magyar) Akadémiával sok nehézsége volt a kiadásra fordított összegek miatt, melyek a meghiúsult terjesztés következtében nem térültek meg. Amennyire meg lehet ítélni, a teljes kiadványt bezúzták.” Valóban, előkerült Tigyi József professzor Szimon Eljevics Snol'-hoz (a szerkesztőbizottság másik orosz tagjához) írt levele, melyben megköszöni fáradozását, és kéri, hogy az átadott példányokat juttassa el szovjet tudósoknak. Bár a mű nem került kereskedelmi forgalomba a Szovjetunióban, így mégis megjelenhetett értö, orosz nyelvü recenzió egy népszerü folyóiratban (Винберг, 1984).

A Szovjetunióban csak évszázadunkban adták ki újra az Elméleti biológiát. Több kiadás közül a Jurij P. Golikov, az Össz-szövetségi Kísérleti Orvostudományi Intézet Múzeumának Igazgatója szerkesztette kötet érdemel külön említést (3. kép C - Бауэр, 2002). A kötetben megjelent Bauer életrajza Bauer fiának és a kötet szerkesztőjének tollából (Бауэр, М.-Голиков, 2002), valamint Bauer elméletének elemzése és értékelése.

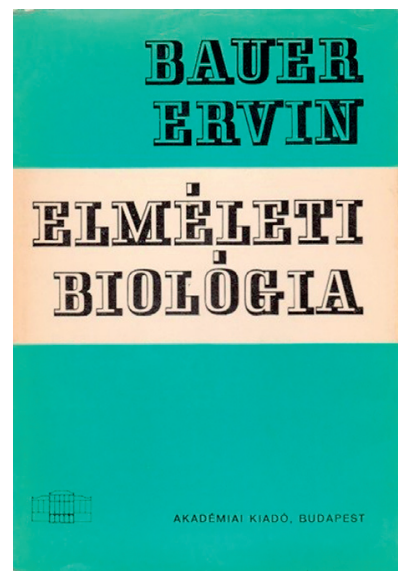

A

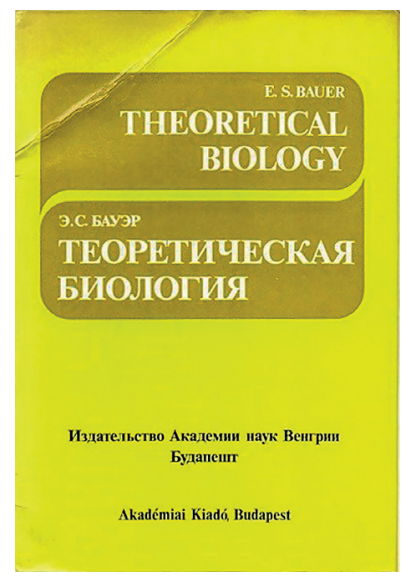

B

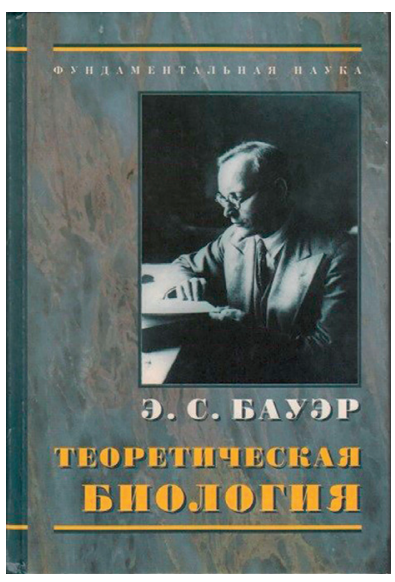

C

3. kép. Az Elméleti biológia posztumusz kiadásai

A: az Akadémiai Kiadó kiadásában megjelent első újnyomat (1957), B: kétnyelvű kiadás (1982),

C: a szentpétervári Rosztok Kiadó kiadása (2002)

Közben nem voltak tétlenek azok sem, akik titokban hozzájutottak Bauer müvéhez, és értékesnek tartották munkásságát. Lev A. Blumenfeld 1974. évi múvében 
a molekuláris biofizika problémáit tárgyalja a nemegyensúlyi termodinamika szempontjából. Idézi Bauer könyvét, és párhuzamot von Prigogine közelmúltbeli és Bauer régebbi tevékenysége között. E könyv németül is megjelent (Blumenfeld, 1977, 32., 110.).

A biofizikus Szimon Eljevics Snol' (sz. 1930) Bauer emlékének egyik legnagyobb támogatója. 1997-ben jelent meg híres könyvének első kiadása, az Orosz Tudomány hösei, gazemberei és megalkuvói, melyet több kiadás követett. A 14. fejezet Bauer Ervinről szól (Шноль, 2010). Szenvedélyesen ír Bauer sorsáról, akit az orosz tudomány hősének tart. Az Orosz Tudományos Akadémia Bauer születésének 100. évfordulójára rendezett konferenciáját ő szervezte meg (Шноль et al., 1993). Ezen huszonkét elöadás hangzott el, és itt került először nyilvánosságra Bauer egy később felbukkant, 1935-ben tartott előadásának szövege.

A 20. század második felének elméleti biológiájában fontos szerepet játszott a nemegyensúlyi termodinamika (von Bertalanffy, Prigogine stb.). Bauer szemlélete hasonlított a nemegyensúlyi termodinamika kiindulópontjához (Elek-Müller, 2019). Ezért Bauer múve áttörte az orosz nyelv béklyóját - de csak halála után fél évszázaddal. „Figyelemre méltó és nyilván nem véletlen Bauer ezen és további gondolatainak messzemenő párhuzama Bertalanffy 1932 évi gondolataival." (Penzlin, 1993, 103.) Bauer és a korai Bertalanffy rokonságára további német biológusok is felfigyeltek (Bruckmann, 2000; Alt, 2010).

„Bauer Ervin a tudomány történetébe mint az elméleti biológia egyik megalapítója vonul be." (Tokin, 1965b, 117.) Tokin jóslata talán teljesült volna, ha Bauer fő műve megjelenésekor nemzetközileg is ismertté válik, szerzője életben marad, és reagálhat tudóstársai véleményére. Mivel nem ez történt, munkája csak „második hazájában” - Oroszországban - váltott ki szenvedélyes vitákat (ElekMüller, 2019). Ez Bauer munkásságának tragikuma. Ez ihlette Borisz Georgijevics Rezsabek orosz biofizikus Bauer Ervin emlékére írt versét (Бауэр, М., 2003, 286-287.), melyet itt Hetényi Zsuzsa fordításában adunk közre. Bauer neve magyarul parasztot jelent, ez oroszul kresztyjanyin (крестьянин), és az orosz szó - a magyarban is - a keresztre emlékeztet. Bauer sorsát ezzel az áthallással színezi a költő.

Permanens egyensúlytalanság,

Ragyogó elmék,

Pengő érc a daluk,

Hisznek a fényes jövőben,

Az embertömegek erejében.

Lendületböl zuhantak bele

A legrosszabb, sorsrontó gödrökbe,

A Történelem fekete lyukaiba

Fekete akarat lökte öket. 
Hol vagytok, alkotók, Kik jobb sorsra vágytatok? Hol? - Az anyag esik szét, Vagy Felső Akarat ítél?

Mi szörnyübb, mint a könyvelés, Amely nem enged fölöslegest?

A Bauer név annyit tesz - paraszt. Kereszt ez, nem túl vidám.

De mintha mágnesként vonzaná A permanens egyensúlytalanságot, Új dalokkal jövünk mi, Viharzó ötletekkel, Permanensen egyensúlytalanokkal Vagyis pusztán elevenekkel.

\section{IRODALOM}

Alt, W. (2010): Entwicklung der theoretischen Biologie und ihre Auswirkung auf die Disziplingenese im 20. Jahrhundert. In: Kaasch, J. - Kaasch, M. (Hrsg.): Verhandlungen zur Geschichte und Theorie der Biologie, Band 15. Berlin: VWB-Verlag, 103-135.

Bauer, E. (1920): Die Grundprinzipien der Rein Naturwissenschaftlichen Biologie und ihre Anwendungen in der Physiologie und Pathologie. (Vorträge und Aufsätze über Entwicklungsmechanik der Organismen 26) Berlin: Springer, https://link.springer.com/book/10.1007/9783-662-34612-9

Bauer E. (1967): Elméleti biológia. Budapest: Akadémiai Kiadó

Bauer, E. S. / Бауэр, Э. С. (1982): Theoretical Biology / Теоретическая Биология /. Reprint of the 1935 edition with a preface, a biographical and critical essay. Перепечатка издания 1935 г., дополненная предисловием, биографическим очерком и критической статьей (in Russian with an extended summary in English). (Frank, G. M. - Tigyi, J. - Shnol, S. E. - Zamyatnin, A. A. eds.) Budapest: Akadémiai Kiadó

Blumenfeld, L. A. (1977): Probleme der molekularen Biophysik. Berlin: Akademie Verlag

Bruckmann, S. (2000): The Organism and the Open System. Ervin Bauer and Ludwig von Bertalanffy. Annals of the New York Academy of Sciences, 90, 291-300. DOI: 10.1111/j.17496632.2000.tb06288.x, https://www.researchgate.net/publication/12498569_The_Organism and the_Open_System_Ervin_Bauer_and_Ludwig_von_Bertalanffy

Einstein, A. (1950): Out of My Later Years. New York: Philosophical Library

Elek G. - Müller M. (2019): Bauer's Theoretical Biology Debated. Orvostörténeti Közlemények, 65, 47-61. http://real-j.mtak.hu/13936/1/Orvostorteneti\%20Kozlemenyek\%202019.pdf

Müller M. (2005): A Martyr of Science, Ervin Bauer (1890-1938). Hungarian Quarterly, 46, 123-131. http://old.ihst.ru/projects/sohist/papers/hq/2005/123-131.pdf

Müller M.- Elek G. (2016): A Biology Textbook edited by Ervin Bauer in 1935 and its Subsequent Fate. Orvostörténeti Közlemények, 62, 85-89. https://library.hungaricana.hu/hu/view/ORSZ ORVO_OK_2016_234_237/?pg=86\&layout $=$ s

Penzlin, H. (1993): Was ist theoretische Biologie? Biologisches Zentralblatt, 112, 100-107. 
Tokin, B. P. (1965a): Az elméleti biológia és Bauer Ervin magyar és szovjet tudós munkássága. MTA Biológiai Tudományok Osztályának Közleményei, 6, 219-232.

Tokin, B. P. (1965b): Az elméleti biológia és Bauer Ervin munkássága. Budapest: Akadémiai Kiadó

Zakharova, E. T. - Kolmakov, N. N. - Sokolov, A. V. (2018): Memorial Plate Unveiled in Memory of Staff of the Institute of Experimental Medicine Who Were Victims of Political Repression. Медицинский Академический Журнал, 18, 73-94. DOI: 10.17816/MAJ18473-91

Бауэр, Э. С. (1930): Физические основы в биологии. Москва: Изд. Мособлисполкома

Бауэр, Э. С. (1935): Теоретическая Биология. Москва-Ленинград: Изд. ВИЭМ

Бауэр, Э. С. (2002): Теоретическая Биология. Санкт-Петербург: Росток

Бауэр, М. Э. (2003): Воспоминание обыкновенного человека. Петергоф: АСПИН

Бауэр, М. Э. - Голиков, Ю. П. (2002): Трагическая судьба Эрвина Симоновича Бауэра. In: Бауэр, Э. С. (2002): Теоретическая Биология. Санкт-Петербург: Росток, 7-23.

Винберг, Г. Г. (1984): «Устойчивое неравновесие живого». Природа, 2, 120-122.

Шноль, С. Э. - Головлев, Е. Л. - Сунгуров, А. Ю. - Воробьева, И. Г. (eds.) (1993): Эрвин Бауэр и Теоретическая Биология. /К 100-летию со дня рождения./ Сборник научных трудов, Пущино: Пущинский Научный Центр, Российская Академия Наук

Шноль, С. Э. ( 2010): Эрвин Симонович Бауэр /1890 - 1937/ «Теоретическая Биология», глава 14. In: Шноль, С. Э.: Герои, злодей и конформисты российской науки. 4. еd. Москва: Либроком, 218-230. 